\title{
ANALISA UNSUR HARA MAKRO PUPUK ORGANIK CAIR (POC) DARI LIMBAH INDUSTRI KERIPIK NENAS DAN NANGKA DESA KUALU NENAS DENGAN PENAMBAHAN URIN SAPI DAN EM4
}

\author{
Rahmadini Syafri, Chairil, Denise Simamora \\ Program Studi Kimia, Fakultas MIPA dan Kesehatan \\ Universitas Muhammadiyah Riau \\ J1. Tuanku Tambusai Ujung, Pekanbaru 28291, Riau \\ e-mail: rahmadini_syafri@yahoo.com
}

\begin{abstract}
ABSTRAK
Tujuan penelitian ini ialah pembuatan produk pupuk organik cair yang memiliki kualitas setara dengan POC komersil dengan memanfaatkan limbah dari industri pembuatan keripik nenas dan nangka serta limbah urin sapi secara fermentasi dengan aktivator EM4 dan aditif tetes tebu (molasses) untuk meningkatkan kandungan hara makro dn mikro sehingga dihasilkan pupuk organik cair kualitas tinggi sesuai dengan standar baku mutu pupuk organik cair Permentan No.28/Permentan/OT140/2/2009. Berdasarkan data keseluruhan hasil pengukuran kadar pupuk organik cair yang dibuat dengan 3 variasi komposisi $\left(\mathrm{POC}_{1}, \mathrm{POC}_{2}\right.$ dan $\left.\mathrm{POC}_{3}\right)$, menunjukkan bahwa pupuk organik cair yang terbaik adalah POC1 dengan variasi komposisi yaitu 3 liter limbah cair kulit nenas dan nangka dengan penambahan 9 liter limbah urin sapi. Waktu optimum fermentasi untuk pembuatan pupuk organik cair dari campuran limbah cair kulit nenas dan nangka serta urin sapi adalah 14 hari karena nilai kadar hara makro dan mikro optimum diperoleh pada waktu tersebut. Kadar hara makro untuk Nitrogen total yang optimum didapati pada sampel POC1 yaitu $0.03 \%$, Fosfor $\left(\mathrm{P}_{2} \mathrm{O}_{5}\right)$ optimum diperoleh juga dari sampel POC1 yaitu $0.007 \%$ dan Kalium $\left(\mathrm{K}_{2} \mathrm{O}\right)$ optimum diperoleh juga dari sampel POC1 yaitu $0.29 \%$.
\end{abstract}

Kata kunci: POC, molasses, urin sapi, aktivator EM4, bioreaktor

\section{PENDAHULUAN}

Saat ini penggunaan pupuk anorganik di kalangan petani masih cukup tinggi. Kebutuhan pupuk untuk pertanian semakin banyak, namun tidak seimbang dengan produksi pupuk dan mahalnya harga pupuk. Penggunaan pupuk anorganik yang berlebihan dalam jangka waktu lama justru akan merugikan karena dapat merusak lingkungan seperti struktur tanah menjadi keras dan mikroorganisme tanah semakin berkurang yang berakibat pada menurun nya produktivitas tanah (handayani dkk, 2015). Dalam menanggapi hal tersebut, berbagai upaya teknologi alternatif telah dilakukan dengan memanfaatkan limbah untuk memproduksi pupuk organik yang ramah lingkungan. Pupuk organik merupakan hasil fermentasi atau dekomposisi dari bahan organik seperti tanaman, hewan atau limbah organik lainnya (Indriani, 2002). Pupuk organik berdasarkan bentuknya dibedakan menjadi dua macam yaitu pupuk organik padat dan pupuk organik cair (Hadisuwito, 2012). Pupuk organik cair memiliki kelebihan dibandingkan dengan pupuk padat yaitu unsur hara yang dikandung lebih cepat tersedia dan mudah diserap akar tanaman. Sumber bahan baku pupuk organik tersedia dengan jumlah yang melimpah terutama dalam bentuk limbah, yaitu limbah rumah tangga, limbah industri, limbah peternakan dan lainnya (Nasarudin dan Rosmawati, 2009).

Salah satu agroindustri yang memiliki prospek yang cerah di Kabupaten Kampar-Riau adalah agroindustri keripik nenas dan nangka. Agroindustri ini merupakan agorindustri yang mengolah buah segar nenas dan nangka melalui berbagai proses untuk menjadi keripik. Dari proses pembuatan keripik ini akan menghasilkan kulit, mahkota, bonggol ataupun jerami nangka yang menjadi limbah. Limbah ini belum dimanfaatkan hanya dibuang di kebun/halaman sehingga memungkinkan terjadinya pencemaran seperti bau dan pencemaran air tanah karena air lindi yang terbentuk. Limbah produksi keripik nenas dan nangka ini sebetulnya dapat dimanfaatkan menjadi produk yang bermanfaat, ramah lingkungan dan bernilai ekononomi salah satunya sebagai bahan pembuatan pupuk kompos (takiyah dan sriharti, 2008). 
Disamping itu limbah dari peternakan juga dapat dimanfaatkan sebagai alternatif dalam pembuatan pupuk organik cair. Salah satu peternakan yang banyak dikenal adalah peternakan sapi. Usaha peternakan sapi dengan skala lebih dari 20 ekor dan relatif terlokalisasi akan menimbulkan pencemaran lingkungan. Satu ekor sapi dengan bobot 400-500 $\mathrm{kg}$ dapat menghasilkan limbah padat dan cair sebesar 27,5$30 \mathrm{~g} / \mathrm{ekor} / \mathrm{hari}$ (Martinsari, dkk, 2010). Data yang diperoleh dari Badan Pusat Statistik (BPS) Provinsi Riau tahun 2013, jumlah populasi ternak sapi mencapai 175.679 ekor. Jumlah populasi yang tinggi ini akan menyebabkan limbah yang terhasil juga semakin tinggi, sedangkan pengelolaan limbah cair peternakan itu sendiri masih sangat kurang. Implikasinya kondisi ini akan berdampak negatif terhadap lingkungan seperti pencemaran air dan udara serta sumber penyakit. Padahal dari segi kandungan unsur haranya, pupuk kandang cair dari urin sapi ini memiliki kandungan hara yang lebih tinggi dibandingkan kotoran padatnya (Lingga, 1999).

Dari kondisi dan situasi diatas, penulis tertarik melakukan penelitian lanjutan mengenai pembuatan pupuk organik cair memanfaatkan limbah dari industri pembuatan keripik nenas dan nangka serta limbah urin sapi secara fermentasi dengan aktivator EM4 dan aditif tetes tebu (molasses) untuk meningkatkan kandungan hara makro dan mikronya sehingga dihasilkan pupuk organik cair kualitas tinggi sesuai dengan standar baku mutu pupuk organik cair Permentan No.28/Permentan/OT140/2/2009.

\section{METODOLOGI PENELITIAN}

\section{Persiapan Alat dan Bahan}

Peralatan yang digunakan dalam fermentasi pupuk organik cair adalah bioreaktor, pengaduk, $\mathrm{pH}$ meter, sarung tangan, tisu dan termometer. Sedangkan peralatan yang digunakan dalam analisa adalah berbagai peralatan gelas laboratorium yang biasa digunakan, buret $50 \mathrm{ml}$, alat destilasi, labu kjedhal, kertas saring Whatman No.41.

Bahan yang digunakan dalam proses pembuatan dan analisa pupuk organik cair adalah limbah kulit, mahkota, bonggol nanas, limbah jerami nangka, urin sapi, EM-4 (Effective Microorganism-4), gula pasir (molasses), air suling, asam sulfat-salisilat, larutan asam sulfat $\left(\mathrm{H}_{2} \mathrm{SO}_{4}\right)$ pekat $98 \%$, larutan asam sulfat $\left(\mathrm{H}_{2} \mathrm{SO}_{4}\right)$ $0,05 \mathrm{~N}$, Asam borat $\left(\mathrm{H}_{3} \mathrm{BO}_{3}\right) 1 \%$, natrium hidroksida $(\mathrm{NaOH})$, Indikator Conway, $\mathrm{HCl}$ pekat $37 \%, \mathrm{HNO}_{3}$ pekat $65 \%, \mathrm{HClO}_{4}$ pekat $70 \%$, pereaksi molibdovanadat.

\section{Populasi dan Persiapan Bahan POC}

Sampel dalam penelitian ini adalah limbah nenas dan nangka yang diambil dari pabrik industri keripik nenas dan nangka yang ada di Desa Kualu Nenas, Jalan Raya PekanbaruBangkinang. Limbah nenas dan nangka ini terlebih dahulu di blender sampai halus (ditambahkan air suling untuk proses penghancuran). Sedangkan limbah cair urin sapi dari peternakan sapi di Pekanbaru. Masingmasing sampel terlebih dahulu diukur $\mathrm{pH}$ awalnya dan kemudian dicampurkan untuk proses fermentasi lebih lanjut dan dilakukan analisis kadar nitrogen, fosfor dan kaliumnya.

\section{Pembuatan Tetes Tebu (molasses)}

Panaskan $5000 \mathrm{ml}$ air (5 L) didalam panci hingga medidih dan masukkan $5 \mathrm{Kg}$ gula. Diaduk sampai gula larut kemudian didinginkan, disaring dan dimasukkan kedalam botol (Ardiningtyas, 2013).

\section{Aktivasi EM4}

EM4 yang masih dalam keadaan tidur (dormant) diaktifkan dengan memberikan makanan dan air. Pengaktifan dilakukan dengan menambahan air dan air gula (molasses) dengan perbandingan $250 \mathrm{ml} \mathrm{EM} 4+250 \mathrm{ml}$ air gula (molasses) $+5000 \mathrm{ml}$ (5L) air (konsentrasi EM4 $5 \%$ ). Kemudian difermentasi selama 5 hari pada suhu ruang (Munawaroh, 2013).

\section{Proses Fermentasi Pupuk Organik Cair}

Siapkan sebanyak 3 bioreaktor berkapasitas 19 liter (masing-masing dengan kode POC1, POC2, POC3) dengan komposisi:

POC1: 3 L limbah nenas dan nangka cair +9 $\mathrm{L}$ ml urin sapi $+1.5 \mathrm{~L}$ EM4 aktif $+1.5 \mathrm{~L}$ tetes tebu (Molasses)

POC2: 9 L limbah nenas dan nangka cair +3 $\mathrm{L} \mathrm{ml}$ urin sapi $+1.5 \mathrm{~L} \mathrm{EM} 4$ aktif $+1.5 \mathrm{~L}$ tetes tebu (Molasses) 
POC3: $6 \mathrm{~L}$ limbah nenas dan nangka cair +6 $\mathrm{L}$ ml urin sapi $+1.5 \mathrm{~L} \mathrm{EM} 4$ aktif $+1.5 \mathrm{~L}$ tetes tebu (Molasses)

Larutan diaduk agar homogen dan kemudian difermentasi selama 21 hari. Pada hari ke-0, 7, 14 dan 21 sampel diambil dan diukur kadar hara makro dan mikro.

\section{HASIL DAN PEMBAHASAN}

Pembuatan pupuk organik cair (POC) ini dilakukan dengan cara mencampurkan limbah kulit nenas dan nangka cair serta limbah urine sapi dengan berbagai variasi dan diberi kode, yaitu POC1, POC2 dan POC3, kemudian ditambahkan aktivator EM4 dan aditif tetes tebu masing-masing sebanyak $1.5 \mathrm{~L}$ dan $1.5 \mathrm{~L}$. Pada hari ke-0, 7, 14 dan 21 dilakukan pemanenan pupuk organik cair untuk dilakukan analisis kadar haranya. Hasil pengamatan pengukuran kadar hara makro dapat dilihat pada tabel 1 dibawah.

Pemanenan pupuk organik cair yang dilakukan pada hari ke-0, 7, 14 dan 21 untuk mengetahui apakah proses fermentasi sudah berlangsung dengan menganalisis kadar hara makro yaitu nitrogen, fosfor, kalium. Penentuan kadar nitrogen pada pupuk organik cair hasil fermentasi dianalisis dengan metode makro kjedahl. Pengukuran kuantitatif kadar fosfor pada pupuk organik cair hasil fermentasi dianalisis dengan metode spektro fotometer UV-Vis yang membentuk kompleks molibdo fosfovanadat. Sementara itu penentuan kadar kalium menggunakan metode spektrofotometer serapan atom (SSA).

\section{Hasil Uji Kadar Nitrogen (N)}

Penentuan kadar nitrogen pada pupuk organik cair menggunakan metode makro kjedahl meliputi proses destruksi, destilasi dan titrasi. Pada proses destruksi masing-masing POC ditambahkan dengan asam sulfat pekat dan tembaga (II) sulfat yang berfungsi sebagai katalisator agar proses berlangsung cepat dan suhu pada saat destruksi berkisar antara 300$400^{\circ} \mathrm{C}$. Proses destruksi selesai apabila larutan berubah menjadi jernih atau tidak berwarna. Reaksi yang terjadi pada tahap destruksi adalah: Norganik $+\mathrm{H}_{2} \mathrm{SO}_{4} \rightarrow\left(\mathrm{NH}_{4}\right)_{2} \mathrm{SO}_{4}+\mathrm{H}_{2} \mathrm{O}+\mathrm{CO}_{2}$

Tabel 1. Hasil Uji Kadar Hara Makro Pupuk Organik Cair

\begin{tabular}{|c|c|c|c|c|c|c|}
\hline \multirow{2}{*}{ Kadar (\%) } & \multirow{2}{*}{ Kode Sampel } & \multicolumn{4}{|c|}{ Fermentasi ke- } & \multirow{2}{*}{ Syarat Mutu } \\
\hline & & O hari & 7 hari & 14 hari & 21 hari & \\
\hline \multirow{3}{*}{ Nitrogen $(N)$} & POC1 & 0.03 & 0.02 & 0.03 & 0.04 & \multirow{3}{*}{$<2 \%$} \\
\hline & POC2 & 0.04 & 0.07 & 0.04 & 0.04 & \\
\hline & POC3 & 0.05 & 0.01 & 0.04 & 0.04 & \\
\hline \multirow{2}{*}{ Kadar (\%) } & \multirow{2}{*}{ Kode Sampel } & \multicolumn{4}{|c|}{ Fermentasi ke- } & \multirow{2}{*}{ Syarat Mutu } \\
\hline & & 0 hari & 7 hari & 14 hari & 21 hari & \\
\hline \multirow{3}{*}{ Fosfor (F) } & POC1 & 0.004 & 0.005 & 0.007 & 0.015 & \multirow{3}{*}{$<2 \%$} \\
\hline & POC2 & 0.001 & 0.004 & 0.006 & 0.014 & \\
\hline & POC3 & 0.004 & 0.004 & 0.007 & 0.014 & \\
\hline \multirow{2}{*}{ Kadar $(\%)$} & \multirow{2}{*}{ Kode Sampel } & & Fer & tasi ke- & & \multirow{2}{*}{ Syarat Mutu } \\
\hline & & 0 hari & 7 hari & 14 hari & 21 hari & \\
\hline \multirow{3}{*}{ Kalium (K) } & POC1 & 0.22 & 0.22 & 0.29 & 0.21 & \multirow{3}{*}{$<2 \%$} \\
\hline & POC2 & 0.18 & 0.18 & 0.26 & 0.18 & \\
\hline & POC3 & 0.20 & 0.21 & 0.29 & 0.19 & \\
\hline
\end{tabular}

Selanjutnya dilakukan proses destilasi dengan penambahan natrium hidroksida untuk mengkonversi $\mathrm{NH}_{4}^{+}$ke $\mathrm{NH}_{3}$ diikuti dengan mendidihkan dan hasil kondensasi $\mathrm{NH}_{3}$ ditampung oleh larutan penerima (penampung destilat) yaitu asam borat yang ditetesi dengan indikator conway. Hasil destilat akan berubah menjadi warna hijau karena amonia proses destilasi diikat oleh asam borat yang membentuk ammonium borat. Kemudian proses titrasi dilakukan dengan menggunakan asam sulfat. Titik akhir titrasi ditandai dengan perubahan warna hijau menjadi merah muda. Dari Tabel 1 menunjukkan bahwa kandungan $\mathrm{N}$ total tertinggi terlihat pada POC2 dan POC3 dibandingkan POC1. Hal ini terjadi karena banyaknya 
penambahan limbah cair kulit dan mahkota nenas serta nangka yang mengandung kadar $\mathrm{N}$ cukup tinggi, sehingga POC2 memiliki kadar $\mathrm{N}$ tertinggi.

Menurut Mulyadi, dkk (2013) bahwa perubahan nilai $\mathrm{N}$ pada tiap perlakuan tidak sama akibat kecepatan mikroba yang mengurai bahan fermentasi berbeda-beda. Selain itu Dwicaksono, dkk (2013) menyatakan bahwa mikroorganisme selain merombak bahan organik menjadi lebih sederhana, juga menggunakan bahan organik untuk aktivitas metabolisme hidupnya.

Kadar nitrogen selama fermentasi pada POC1 dan POC3 mengalami kenaikan sepeti yang terlihat table 1 hasil pengukuran dari hari ke-7 hingga 21 hari. Kenaikan kadar nitrogen pada pupuk organik cair selama proses fermentasi dapat dilihat pada Gambar 1.

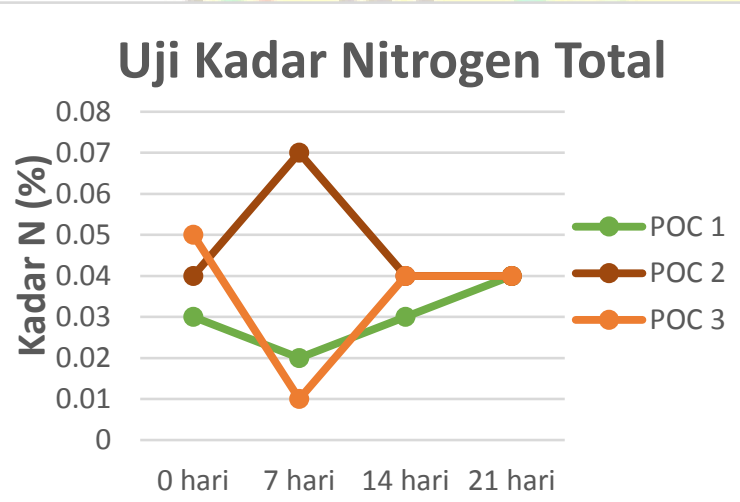

\section{Waktu Fermentasi}

\section{Gambar 1. Grafik Pengukuran Kadar Nitrogen Pupuk Organik Cair}

\section{Hasil Uji Kadar Fosfor (P)}

Tahap analisis kadar fosfor yaitu dengan destruksi yang bertujuan untuk mengoksidasi senyawa organik yang terdapat dalam sampel pupuk organik cair dengan menggunakan asam nitrat pekat $\left(\mathrm{HNO}_{3}\right)$ dan asam perklorat $\left(\mathrm{HCLO}_{4}\right)$ pekat. Kemudian sampel di destruksi hingga larutan berubah menjadi bening atau tidak bewarna. Pada awal destruksi timbul gas berwarna kecoklatan dan menimbulkan bau yang sangat menyengat sehingga dilakukan di dalam lemari asam. Kemudian larutan didinginkan diencerkan dengan akuades hingga tanda batas. Pengukuran kuantitatif kadar fosfor dilakukan dengan spetrofotometer UV-Vis menggunakan campuran larutan amonium molibdovanadat sebagai pembentuk kompleks berwarna.

Hasil uji pada hari ke-0 seperti yang terlihat pada Tabel 1 menunjukkan bahwa kadar fosfor tertinggi diperoleh pada POC1 dibandingkan POC2 dan POC3 karena variasai komposisi limbah urin sapi terbanyak pada POC1. Hasil uji kadar fosfor hari ke-7, 14 dan 21 pada POC1 mengalami kenaikan selama proses fermentasi. Begitu juga dengan POC2 dan POC3 didapati mengalami kenaikan pada pengukuran hari ke-7, ini disebabkan oleh mikroba pengurai bekerja secara optimal, sehingga pada hari ke-21 dengan kenaikan kadar maksimum (lihat Gambar 2).

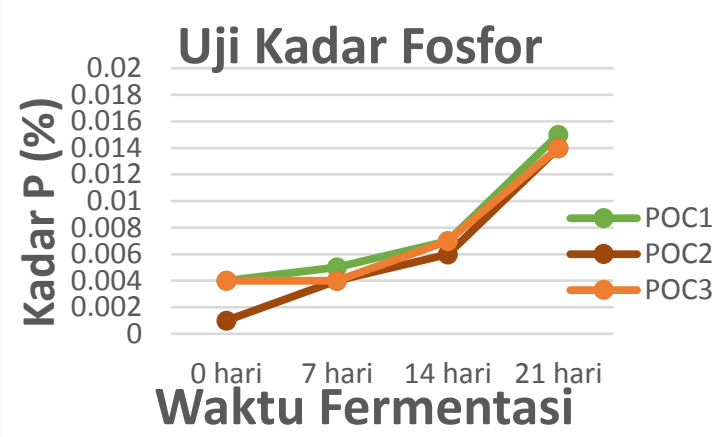

\section{Gambar 2. Grafik Pengukuran Kadar Fosfor Pupuk Organik Cair}

Mikroorganisme selain merombak $\mathrm{P}$ organik menjadi $\mathrm{P}$ anorganik juga menggunakan unsur $\mathrm{P}$ untuk aktivitas metabolisme hidupnya (Notohadiprawiro, 1999). Kandungan fosfor dalam pupuk organik cair juga lebih tinggi karena aktivitas bakteri proteolitik dalam EM4 mampu merombak protein menjadi asam amino. Fosfat yang terikat dalam rantai panjang akan larut dalam asam organik yang dihasilkan bakteri pelarut fosfor (Subagyo dan Setyati, 2012).

\section{Hasil Uji Kadar Kalium (K)}

Penentuan kadar kalium menggunakan spektrofotometer serapan atom (SSA). Sampel terlebih dahulu didestruksi sebelum dianalisis dengan tujuan mengoksidasi senyawa organik yang terdapat dalam sampel dengan menggunakan asam kuat HNO3 dan HCLO4. Pada saat destruksi timbul asap bewarna kuning kecoklatan kemudian dilanjutkan hingga sampel berubah warna menjadi bening atau tidak berwana. Larutan ini didinginkan dan diencerkan 
ke dalam labu ukur $500 \mathrm{ml}$ dengan akuades hingga tanda batas agar tidak mengkristal.

Kemudian larutan disaring untuk mendapatan larutan yang bersih dari kotoran dan kekeruhan. Selanjutnya destilat hasil penyaringan di pipet sesuai kebutuhan untuk diencerkan kedalam labu ukur $100 \mathrm{ml}$ dengan menambahan larutan supressor $5 \mathrm{ml}$ yang meningkatkan limit sensitivitas deteksi dalam sistem pengukuran pada spektrofotometer serapan atom.

Dari Gambar 3 dapat dilihat grafik kandungan kadar kalium. Hasil uji pada hari ke-0 seperti yang terlihat pada Tabel 1 menunjukkan bahwa kadar K tertinggi diperoleh pada POC1 dibandingkan POC2 dan POC3 karena variasai campuran limbah urin sapi terbanyak pada POC1. Hasil uji kadar K hari ke-7 dan 14 pada POC1 mengalami kenaikan selama proses fermentasi. Begitu juga dengan POC2 dan POC3 didapati mengalami kenaikan pada pengukuran hari ke-7, ini disebabkan oleh mikroba pengurai bekerja secara optimal, sehingga pada hari ke-14 dengan kenaikan kadar optimum POC1, POC2, dan POC3.

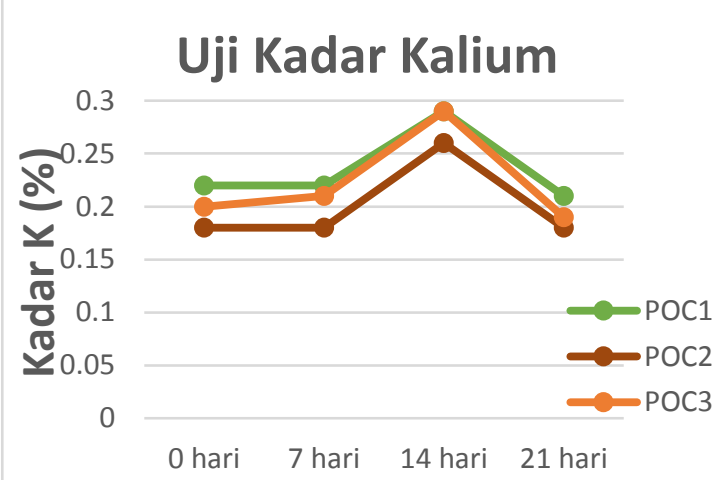

Waktu Fermentasi

\section{Gambar 3. Grafik Pengukuran Kadar Kalium Pupuk Organik Cair}

Mikroorganisme selain merombak nitrogen juga menggunakan kalium untuk aktivitas metabolisme hidupnya. Menurut Mawardi dan Purnomo (2014) kalium digunakan oleh mikroorganisme dalam bahan substrat sebagai katalisator, dengan kehadiran bakteri dan aktivitasnya akan sangat berpengaruh terhadap peningkatan kandungan kalium.Penentuan kadar kalium menggunakan spektrofotometer serapan atom (SSA).

Penurunan kadar kalium disebabkan oleh aktivitas mikroorganisme dalam mengurai bahan organik yang akan mengurangi kandungan $\mathrm{K}$ pupuk organik cair. Mikroorganisme selain merombak kalium juga menggunakan kalium untuk aktivitas metabolisme hidupnya. Menurut Mawardi dan Purnomo (2014) kalium digunakan oleh mikroorganisme dalam bahan substrat sebagai katalisator, dengan kehadiran bakteri dan aktivitasnya akan sangat berpengaruh terhadap peningkatan kandungan kalium. Selain itu, terbentuknya asam organik selama proses penguraian menyebabkan daya larut unsur-unsur hara seperti $\mathrm{Ca}, \mathrm{P}$ dan $\mathrm{K}$ menjadi lebih tinggi, sementara proses penguraian bahan organik yang dilakukan mikroba akan mengurangi kandungan K pupuk organik cair (Notohadiprawiro, 1999).

\section{KESIMPULAN}

Berdasarkan data keseluruhan hasil pengukuran kadar pupuk organik cair yang dibuat dengan beberapa variasi komposisi, menunjukkan bahwa pupuk organik cair dengan komposisi terbaik adalah POC1 dengan variasi komposisi yaitu 3 liter limbah cair kulit nenas dan nangka dengan penambahan 9 liter limbah urin sapi.

1. Waktu optimum fermentasi untuk pembuatan pupuk organik cair dari campuran limbah cair kulit nenas dan nangka serta urin sapi adalah 14 hari karena nilai kadar hara makro dan hara mikro optimum diperoleh pada waktu tersebut.

2. Kadar hara makro untuk Nitrogen total yang optimum didapati pada sampel POC1 yaitu $0.03 \%$, Fosfor (P2O5) optimum diperoleh juga dari sampel $\mathrm{POC} 1$ yaitu $0.007 \%$ dan Kalium (K2O) optimum diperoleh juga dari sampel POC1 yaitu $0.29 \%$.

\section{DAFTAR PUSTAKA}

Ardiningtyas, T. R. 2013. Pengaruh Penggunaan Effective Microorganism 4 (Em4) dan Molase Terhadap Kualitas Kompos dalam Pengomposan Sampah Organik RSUD dr. R. Soetrasno Rembang. 
Skripsi. Universitas Negeri Semarang, Semarang

Hadisuwito, S. 2007. Membuat Pupuk Kompos Cair. Jakarta: Agromedia Pustaka.

BPS Provinsi Riau. 2013. Jumlah Ternak menurut Jenis dan Kabupaten/Kota. Pekanbaru.

Fatmawaty. Metode Kjedahl. www.chem-istrv.org. (diakses tanggal 22 Oktober 2015).

Handayani, S.H., Yunus, A., \& Susilowati, A. 2015. Uji Kualitas Pupuk Organik Cair dari Berbagai Macam Mikroorganisme Lokal (MOL). Jurnal Biosains Pascasarjana. Universitas Negeri Semarang, Semarang.

Hendayana, S. 1994. Kimia Analitik Instrumen. IKIP Semarang Press, Semarang.

Huda, M. K. 2013. Pembuatan Pupuk organik Cair dari Urin Sapi dengan Aditif Tetes Tebu (Molasses) Metode Fermentasi. Skrip.si. Universitas Negeri Semarang, Semarang.

Lingga, P. 1999. Nutrisi Organik dari Hasil Fermentasi. Pupuk Buatan Mengandung Nutrisi Tinggi, Yogyakarta.

Makiyah, M. 2013. Analisa Kadar N, P, dan K Pada Pupuk Cair Limbah Tahu dengan Penambahan Tanaman Matahari Mesiko. Sripsi. Universitas Negeri Semarang, Semarang

Hidayati, Benito, dkk. 2011. Kualitas Pupuk Cair Hasil Pengolahan Feses Sapi Potong Menggunakan Saccharomyces cereviceae (Liquid Fertilizer Quality
Produced by Beef Cattle Feces Fermentation Using Saccharomyces cereviceae). Jurnal Ilmu Ternak. Bandung: Universitas Padjadjaran.

Manurung, D. 2012. Pembuatan Pupuk Organik Cair dari Limbah Organik dengan Aktivator EM4 dan Analisis N P K pada Pupuk Cair Organik. Skripsi. Universitas Negeri Medan, Medan.

Martinsari, T., Wijayanti, Y., dan Purwanti, E. 2010. Optimalisasi Fermentasi Urine Sapi Dengan Aditif Tetes Tebu (Molasses) untuk Menghasilkan Pupuk Organik Cair yang Berkualitas Tinggi. PKM-GT. Universitas Negeri Malang, Malang.

Nyakpa, M.Y., Lubis, A.M., Pulung, M.A., Amrah, A.G., Munawar, A., Hong. G.B., dan Nurhaj ati, H. 1988. Kesuburan Tanah. Universitas Lampung, Lampung.

Rohman, A. 2007. Kimia Farmasi Analisis. Pustaka Pelajar, Yogyakarta.

Takiyah, S dan Sriharti, 2008. Pemanfaatan Limbah Industri Pengolahan Dodol Nanas Sebagai Kompos Dan Aplikasinya Pada Tanaman Tomat. Balai Besar Pengembangan Teknologi LIPI. Yogyakarta.

Yoska, I., Sri, K., dan Arie, F.M. 2015. Pembuatan Pupuk Kompos Dari Campuran Jerami Nangka Dengan Kotoran Kelinci Menggunakan Dekomposer Ma-11.(Kajian Lama Fermentasi Dan Proporsi Bahan). Universitas Brawijaya, Malang. 